medRxiv preprint doi: https://doi.org/10.1101/2022.03.03.22271862; this version posted March 6, 2022. The copyright holder for this preprint (which was not certified by peer review) is the author/funder, who has granted medRxiv a license to display the preprint in perpetuity.

All rights reserved. No reuse allowed without permission.

\title{
Burden of Disease from Contaminated Drinking Water in Countries with High Access to Safely Managed Water: A Systematic Review
}

\author{
Debbie Lee, Jacqueline MacDonald Gibson, Joe Brown, Jemaneh Habtewold, Heather M. \\ Murphy
}

Water, Health and Applied Microbiology (WHAM) Lab, Department of Epidemiology and Biostatistics, College of Public Health, Temple University, Philadelphia, PA, USA (D Lee PhD, $\mathrm{H}$ M Murphy PhD); Department of Environmental and Occupational Health, School of Public Health, Indiana University, Bloomington, IN, USA (J M Gibson PhD); Department of Environmental Sciences and Engineering, Gillings School of Global Public Health, University of North Carolina at Chapel Hill, Chapel Hill, NC, USA (J Brown PhD); Water, Health and Applied Microbiology (WHAM) Lab, Department of Pathobiology, Ontario Veterinary College, University of Guelph, Guelph, ON, CAN (J Habtewold PhD, H M Murphy PhD)

Correspondence to:

Dr. Heather M. Murphy, Department of Pathobiology, University of Guelph, Guelph, ON, Canada, N1G 2W1

heather.murphy@uoguelph.ca

\begin{abstract}
Background

The vast majority of residents of high-income countries ( $>90 \%)$ reportedly have high access to safely managed drinking water, the highest level of service under the Sustainable Development Goal (SDG) framework. Owing perhaps to the widely held perception of near universal access to high-quality water services in these countries, the burden of waterborne disease in these contexts is understudied.
\end{abstract}

\section{Methods}

We conducted a systematic review of estimates of the disease burden attributed to drinking water in countries where $>90 \%$ of the population has access to safely managed drinking water per official SDG monitoring. We searched PubMed, Web of Science, and SCOPUS for articles published before September 10, 2021.

\section{Findings}

We identified 24 studies reporting estimates for the disease burden attributable to microbial contaminants. Across these studies, the population-weighted average burden of gastrointestinal illness risks attributed to drinking water was about 3,529 annual cases per 100,000 people. Beyond exposure to infectious agents, we also identified 10 studies reporting disease burden, predominantly, cancer risks, associated with chemical contaminants. Across these studies, the pooled population-weighted average of excess cancer cases attributable to drinking water was 1.8 annual cancer cases per 100,000 people.

\section{Interpretation}

These estimates exceed WHO-recommended normative targets for disease burden attributable to drinking water and highlight that there remains important preventable disease burden in these contexts. However, the available literature was scant and limited in geographic scope, disease outcomes, range of microbial and chemical contaminants, and inclusion of subpopulations that could most benefit from water infrastructure investments. These subpopulations include rural, 
medRxiv preprint doi: https://doi.org/10.1101/2022.03.03.22271862; this version posted March 6, 2022. The copyright holder for this preprint (which was not certified by peer review) is the author/funder, who has granted medRxiv a license to display the preprint in perpetuity.

All rights reserved. No reuse allowed without permission.

low-income communities; Indigenous or Aboriginal peoples; and populations marginalized due to discrimination by race, ethnicity, or socioeconomic status. Studies quantifying drinking waterassociated disease burden in countries with reportedly high access to safe drinking water, with a focus on specific subpopulations and promoting environmental justice, are needed.

\section{$\underline{\text { Research in context }}$}

\section{Evidence before this study}

Although the burden of disease associated with unsafe drinking water in low- and middle-income countries has been subject of much research, there is uncertainty about the magnitude and nature of this disease burden in high-income countries and countries where access to safely managed drinking water is $>90 \%$. To assess the magnitude of this burden in countries with high levels of access to high quality water, we conducted a systematic review of estimates of the disease burden attributed to drinking water in countries where $>90 \%$ of the population has access to safely managed drinking water as defined by the WHO/UNICEF Joint Monitoring Programme for Water Supply, Sanitation and Hygiene (JMP). We searched PubMed, Web of Science, and SCOPUS for relevant articles published before September 10, 2021. We searched for articles including "burden of disease" OR "disease burden" OR "gastrointestinal illness" anywhere in the text. From among these articles, we selected those with the terms "drinking water" OR "tap water." From this reduced set, we selected articles reporting on countries with $>90 \%$ safe water access and including estimates of cases, hospitalizations, or deaths related to drinking water contamination. Additional articles were identified from consultations with subject-matter experts. Only articles in English were recovered, which may have biased our results towards specific countries.

\section{Added value of this study}

To our knowledge, this is the first global review of its kind to identify burden of waterborne disease estimates associated with microbiological contaminants as well as chemical contaminants found in drinking water, specifically in countries with reportedly high access $(>90 \%)$ to safely managed drinking water. Despite the perception that high quality water is ubiquitous in these countries, we found that burden estimates in these countries exceeded WHO-recommended targets for disease burden attributable to unsafe drinking water. This review also highlighted the gaps in our understanding of waterborne disease burden across and within countries where access to high quality drinking water is common.

\section{Implications of all the available evidence}

Even though the levels of access to safely managed drinking water are high in many high-income and some middle-income countries, there remains a potentially important preventable disease burden in these high-income countries. Our review suggests that further burden research expanding the scope of contaminants, disease outcomes, geographic area, and vulnerable subpopulations within countries is necessary. Currently, available evidence is insufficient to support rational decision-making and to prioritize public investment to protect the health of marginalized communities. These groups include rural, low-income communities; Indigenous or Aboriginal peoples; and populations marginalized due to discrimination by race, ethnicity, or socioeconomic status.

\section{Introduction}


medRxiv preprint doi: https://doi.org/10.1101/2022.03.03.22271862; this version posted March 6, 2022. The copyright holder for this preprint (which was not certified by peer review) is the author/funder, who has granted medRxiv a license to display the preprint in perpetuity.

All rights reserved. No reuse allowed without permission.

Since 1990, the WHO/UNICEF Joint Monitoring Programme for Water Supply, Sanitation and Hygiene (JMP) has reported on access to safe drinking water worldwide. WHO/UNICEF defines drinking water as safely managed if it comes from an improved source that is accessible on premises, available when needed, and free of fecal and priority chemical contamination. JMP data indicate that in countries classified by the World Bank as low- or middle-income (per-capita incomes $<\$ 12,696$ ), major gaps in safe water access remain, with $46.6 \%$ of the population unserved as of 2017. ${ }^{1}$ These gaps manifest in high disease burdens. Recent estimates attribute unsafe drinking water as the cause of $36 \%$ of the 1.4 million annual diarrheal deaths worldwide in low- and middle-income countries (LMICs). ${ }^{2}$

In contrast to the situation in LMICs, JMP data suggest that in high-income countries (HICs), most of the population has safe water, with an average of $<3 \%$ lacking access as of 2017 (Table S1). However, the JMP's national-scale data and data collection methods can mask local-scale inequities in HICs, such as in rural, low-income, and minority communities. ${ }^{3,4}$ They can also lead to a misconception that water problems of HICs have been solved, resulting in underinvestment in maintaining and extending water infrastructure. For example, a recent commentary on infrastructure investment needs in the United States (US) noted "Americans expect the water flowing from their kitchen faucets to be clean and safe," yet "water infrastructure is particularly vulnerable to neglect" because it "is buried underground or removed from public view, and is thus easily ignored."

Improved understanding of the burden of waterborne disease in countries with high access to safely managed drinking water (most high-income and some middle-income countries) can help identify remaining contamination issues and gaps for water infrastructure investments. To support such efforts, we conducted a systematic review to identify studies estimating the disease burden attributed to contaminated drinking water in the 64 countries/territories with $>90 \%$ safe water access per the JMP definition (Table S1, Figure S1). Among these countries/territories, 54 are classified as high-income; 7 are upper middle income (per-capita incomes between $\$ 4,096$ and $\$ 12,695$ ), and 3 are lower middle income (per-capita incomes between $\$ 1,046$ and \$4,095). The review was intended to:

1. identify available estimates of waterborne disease burden in countries with high access to safely managed drinking water;

2. evaluate and compare methods to quantify disease burden; and

3. identify gaps in available disease burden estimates.

\section{Methods}

\subsection{Review Method}

We followed the Preferred Reporting Items for Systematic reviews and Meta-Analyses (PRISMA) method. ${ }^{6}$ Table S2 documents study adherence to PRISMA guidelines.

\subsection{Search Strategy}

We searched PubMed, Web of Science, and SCOPUS for relevant articles published before September 10, 2021. First, we searched for articles including "burden of disease" OR "disease 
medRxiv preprint doi: https://doi.org/10.1101/2022.03.03.22271862; this version posted March 6, 2022. The copyright holder for this preprint (which was not certified by peer review) is the author/funder, who has granted medRxiv a license to display the preprint in perpetuity.

All rights reserved. No reuse allowed without permission.

burden" OR "gastrointestinal illness" anywhere in the text. From among these articles, we selected those with the terms "drinking water" OR "tap water." From this reduced set, we selected articles reporting on countries with $>90 \%$ safe water access (Table S1, Figure S1). Last, 14 additional articles were identified from consultations with subject-matter experts. After removal of duplicates, 528 articles remained for screening (Figure S2). Details on the development of search criteria can be found in Text S1.

\subsection{Selection Criteria}

Articles in English meeting these inclusion criteria were considered:

a) burden estimate is for a country with $>90 \%$ safe water access (Table S1) and

b) estimates cases, hospitalizations, or deaths that could be prevented if ingestion of one or more contaminants in drinking water were prevented.

Articles focusing exclusively on exposure to contaminated water via recreation (e.g., swimming in contaminated water), inhalation, or dermal uptake were excluded. At least two independent reviewers screened the 528 articles against these criteria.

\subsection{Data Extraction \& Synthesis}

Disease burden estimates were extracted by co-authors (DL; HM; JMG) using a custom spreadsheet to record estimates, study design, population, disease type(s), contaminant type(s) (microbial or chemical), and drinking water source. To compare estimates across studies, the reported disease burden was converted to incidence per 100,000 population. For some studies, additional adjustments were made to enable cross-study comparisons; Table S3 provides details. All estimates in the custom spreadsheet were confirmed by at least two co-authors. Text S2 outlines data synthesis and visualization approaches.

\section{Results}

Thirty-three articles met the selection criteria. All but one of the articles focused on a single country or union of countries. Of these 32 articles, most $(68.8 \%)$ burden estimates were from the United States or Canada; $12.5 \%$ were from Asia; 9.4\% reported on European countries; and 9.4\% from Australasia (Figure S3, Table S4). Two articles provided estimates from a middleincome country (Iran); the rest, focused on high-income countries.

\subsection{Infectious Diseases}

Twenty-four articles estimated gastrointestinal illness (GI) risks (Table 1). Estimates are difficult to compare across studies because some estimated total GI burden, whereas others quantified the burden only for specific pathogens or specific outcomes (e.g., hospitalization). When sufficient information was available, we scaled results to enable cross-study comparisons (Table S3).

The population-weighted average burden of GI attributable to drinking water was approximately 3,529 cases per 100,000 population (range 40-18,250 per 100,000) across studies that estimated total GI burden or that could be adjusted to estimate this burden. The highest estimate was from a 2006 study by Eisenberg et al., using data from a drinking water intervention trial (Figure 1).

The lowest was from a 2016 North Carolina (US) study that compared three different estimation methods; two resulted in estimates of $\sim 40$ annual cases per 100,000, while the third estimate was 
medRxiv preprint doi: https://doi.org/10.1101/2022.03.03.22271862; this version posted March 6, 2022. The copyright holder for this preprint (which was not certified by peer review) is the author/funder, who has granted medRxiv a license to display the preprint in perpetuity.

All rights reserved. No reuse allowed without permission.

$\sim 6,300$ per 100,000 people. Across studies, the population-weighted standard deviation $(2,535$ per 100,000) was relatively low, just over half the mean.

Of the 24 studies, only five directly estimated the number of deaths attributable to microbial contaminants. These estimates were very low, averaging 1 per 100,000 people annually (range $=$ $7.3 \times 10^{-3}$ to 2.1 per 100,000$)$.

\subsection{Non-infectious Diseases}

Ten articles estimated the disease burden from chemical contaminants in drinking water (Table 2).

Cancers were the most common health outcome considered, included in 7 of the 10 studies (Figure 2). Estimated cancer risks varied depending on the cancer type and contaminants considered. Across all studies with cancer risk estimates, the population-weighted average disease burden was 1.8 excess cases per 100,000 people annually (range $=0.09-2.91$ ).

Two studies, both in the United States, estimated adverse reproductive outcomes from nitrate in drinking water. ${ }^{7,8}$ In both studies, the disease burden was low on a per-capita basis. The highest burden was 1.6 low-birthweight babies per 100,000 people annually.

Surprisingly, despite the recent attention to lead in drinking water resulting from the Flint water crisis (US) and similar events elsewhere, only one study (from the Netherlands) quantified the health burden from lead. ${ }^{9}$ That study, published in 1999, estimated that 11 in 100,000 children were losing 1-3 IQ points as a result of neurocognitive damage from lead in drinking water.

The largest reported fatality risks from chemical contaminants were attributed to arsenic and disinfection byproducts (Figure 2b; Figure 3b), though these risks were very low. Across studies, about $0.1-1.3$ premature annual deaths per 100,000 people were attributed to these contaminants. A 2017 study from North Carolina (US) attributed fewer than 0.0015 excess annual deaths per 100,000 people to gross alpha radiation, volatile organic compounds, and pesticides in drinking water. $^{10}$

\subsection{Comparison of Approaches Across Studies}

Broadly, study methods can be classified as "top-down" or "bottom up" (Tables 1-2).

\subsubsection{Top-Down Approach}

Unlike foodborne illness surveillance, a robust system of waterborne illness surveillance does not exist. In the absence of such a system, some studies use overall disease surveillance data. They estimate the fraction of diseases that may be attributable to water and multiply this fraction by the total number of relevant diseases in the population. The WHO uses this method for its periodic global assessments of the contribution of various risk factors to population health. ${ }^{11}$

Top-down studies have used a range of methods to estimate the attributable fraction. Some use previous epidemiologic studies, combined with estimates of the population fraction exposed to various contamination levels. As an example, Colford et al. ${ }^{12}$ used data from an epidemiologic study in which participants were randomized to receive either an active or sham water treatment 
medRxiv preprint doi: https://doi.org/10.1101/2022.03.03.22271862; this version posted March 6, 2022. The copyright holder for this preprint (which was not certified by peer review) is the author/funder, who has granted medRxiv a license to display the preprint in perpetuity.

All rights reserved. No reuse allowed without permission.

system. DeFelice et al. ${ }^{13}$ obtained information on the distribution of occurrence and concentration of all regulated chemical contaminants in public water systems from state and federal water quality surveillance data. Fractions of illnesses attributable to these exposures were estimated by matching exposure concentrations to relative risks of illness from previous epidemiologic studies.

An alternative top-down method, used by Gibney et al., ${ }^{14}$ relies on elicitation of expert judgments. Gibney et al. relied on 13 expert opinions on the fractions of illness from five different waterborne pathogens. There was wide variation in expert views. For example, for noroviruses, experts' median assessments of the attributable fraction ranged from $2 \%$ to $50 \%$.

Another top-down approach is population intervention modeling, as illustrated in two studies by DeFelice et al. ${ }^{15,16}$ In this approach, disease surveillance data are combined with water source and water quality monitoring data, and a regression model estimating the disease incidence rate as a function of these variables (along with additional controls) is fitted. The number of cases attributable to water contamination is estimated from the regression model by comparing the baseline (observed) rate to the expected rate if water quality were improved.

\subsubsection{Bottom-Up Approach}

The bottom-up approach combines data on microbial or chemical contaminant exposure concentrations with dose-response information from epidemiologic or toxicologic studies. The dose-response functions are used to predict the estimated probability of illnesses for specific exposure concentrations. Those probabilities are then multiplied by the size of the exposed population. A drawback of this approach is that the estimated number of attributable cases could exceed the total number of actual cases - a potential error that the top-down approach avoids. On the other hand, in the absence of sufficiently comprehensive surveillance data, this is the only alternative. ${ }^{17}$

Among studies of the disease burden associated with microbial contamination of drinking water, the bottom-up approach was illustrated by Murphy et al., ${ }^{18}$ Burch et al., ${ }^{19}$ Reynolds et al.,${ }^{20}$ and DeFelice et al. ${ }^{16}$ For example, Murphy et al. used quantitative microbial risk assessment to estimate the disease burden from five pathogens in private wells and small community systems in Canada. Burch et al. used well water monitoring data for eight pathogens, along with published dose-response information, to characterize the burden from these pathogens among residents of Kewaunee County, Wisconsin (US), using private wells. Reynolds et al. estimated the disease burden attributable to microbial contaminants in US drinking water by making assumptions about the prevalence and concentrations of selected pathogens in different water source types and then using literature-derived dose-response information to estimate illness probabilities from these assumed exposures. DeFelice et al. estimated the burden of GI from three reference pathogens in North Carolina community water systems using monitoring data on the occurrence of $E$. coli and a literature review of the ratio of concentrations of each reference pathogen to E. coli.

The bottom-up approach is also common in studies quantifying the disease burden from chemical contaminants. Examples include studies of the disease burden from fluoride ${ }^{21}$ and disinfection byproducts ${ }^{22}$ in drinking water in Iran and characterization of the disease burden 
medRxiv preprint doi: https://doi.org/10.1101/2022.03.03.22271862; this version posted March 6, 2022. The copyright holder for this preprint (which was not certified by peer review) is the author/funder, who has granted medRxiv a license to display the preprint in perpetuity.

All rights reserved. No reuse allowed without permission.

from arsenic in drinking water in the US. ${ }^{23}$ These studies begin by estimating the probability distribution of contaminant exposure across the study population, and they use a dose-response function derived from previous animal or human studies to predict the number of adverse health outcomes associated with each exposure dose.

Overall, this review indicates that the lack of robust surveillance systems hinders estimation of the burden of disease attributable to drinking water contamination. A variety of approaches has been used to develop estimates in the face of limited surveillance data, but there is no single, agreed-upon approach. This methodological uncertainty complicates comparisons across geographic regions and study years.

\section{Discussion}

We found 23 studies that estimated the burden of infectious diseases and 9 that estimated the chemical disease burden - and one study that estimated both - from drinking water contamination in countries with reportedly high access to safely managed drinking water. Among the infectious disease burden studies, nearly all focused exclusively on GI; the average burden across the studies was approximately 3,529 excess GI cases per 100,000 people yearly (Table 1; Figure 1). Among studies of non-infectious diseases attributable to chemical contamination, the majority focused on carcinogens. The excess cancer risk across studies averaged 1.8 cases per 100,000 people yearly (ranging from less than one in one billion to two cases per 100,000 people yearly) (Table 2; Figure 2).

Overall, these results suggest that the risks of GI from drinking water contamination are low in many HICs relative to those in developing nations, but that the risks are still higher than recommended targets established by the WHO's Guidelines for Drinking Water Quality. ${ }^{24}$ The Institute of Health Metrics and Evaluation estimates that globally, the burden of disease from unsafe water is 922 annual disability-adjusted life years (DALYs) per 100,000 people, with the highest burden in sub-Saharan Africa, at 2,813 annual DALYs per 100,000 people. ${ }^{25}$ Using a disability weight of 0.074 for mild diarrhoea as in recent global studies, ${ }^{26}$ the populationweighted average 3,529 annual GI cases per 100,000 people equates to approximately 260 annual DALYs per 100,000 people, or less than one-third the global average and about $90 \%$ less than in the most affected regions. However, the WHO defines "the tolerable burden of disease . . . as an upper limit of $10^{-6}$ DALY per person per year," equivalent to 0.1 per 100,000 people. By this measure, the burden of infectious diseases associated with drinking water contamination is still much higher than desired, even in high-income nations and even for the lowest risk estimates identified in this review (40 annual GI cases per 100,000 people, equivalent to 3 DALYs per 100,000).

Cancer risk estimates also suggest the magnitude of the disease burden associated with drinking water contamination is relatively low but still exceeds the WHO's recommendation of one excess annual cancer case per 100,000 people attributed to drinking water. Across studies, the average cancer risk was about twice this amount.

\section{$\underline{\text { 4.1. Limitations of the Available Studies }}$}


medRxiv preprint doi: https://doi.org/10.1101/2022.03.03.22271862; this version posted March 6, 2022. The copyright holder for this preprint (which was not certified by peer review) is the author/funder, who has granted medRxiv a license to display the preprint in perpetuity.

All rights reserved. No reuse allowed without permission.

This review identified critical gaps in efforts to characterize the disease burden attributable to drinking water contamination in countries with high access to safely managed drinking water. These gaps include a lack of country representation, insufficient spatial resolution in countries with available studies, a limited scope of contaminants considered, and insufficient information to support decision-making about the best ways to decrease the disease burden. Although we attempted to recover estimates from grey literature, only two from New Zealand were found. There may be unpublished estimates that this review did not recover.

\subsubsection{Limited Geographic Representation}

The published disease burden studies covered only 10 of 64 countries/territories reporting $>90 \%$ access to safely managed drinking water. One study covered disease burden in the European Union. More than half of studies are from the United States or Canada. As such, the results of this review may be heavily biased toward these countries.

\subsubsection{Insufficient Spatial Resolution}

Even in countries with available disease burden estimates, the estimates' spatial resolution is insufficient to support decision-making about allocation of resources for infrastructure improvements. Such allocation decisions typically begin at the local level and therefore require local-level estimates highlighting populations most in need of assistance. Most available studies provide estimates for large geographic regions (such as an entire country or a large political subdivision within the country), not for smaller spatial units or special subpopulations. The high risks that some populations may face are subsumed when they are averaged in with the general population receiving high-quality water services. Among studies identified in this review, only Haass et al. ${ }^{27}$ and Beaudeau et al. ${ }^{28}$ looked at specific vulnerable populations. Haass et al. examined the burden associated with communities in El Paso, Texas (US), inadequately served by water and sanitation services. Beaudeau et al. estimated burden in elderly populations in Massachusetts (US).

As an example, small water systems experience water quality and service delivery problems more often than larger systems due to the lack of economies of scale. ${ }^{29-31}$ This is of particular concern when considering that small water systems frequently serve rural, low-income communities. Allaire et al. found that violations of health-based drinking water standards in the US often occur in low-income rural areas. ${ }^{29} \mathrm{~A}$ cross-sectional study of water quality in small and medium water systems in rural Alabama found an association between self-reported GI symptoms and the following water system characteristics: respondent-reported water supply interruption, low water pressure, lack of total chlorine in water, and detection of E. coli in water. $^{32}$

Water systems serving communities of color also are more likely to experience water quality problems, with a consequent disease burden that can be masked in studies lacking sufficient spatial resolution. In Canada, boil-water advisories for systems serving indigenous communities are common - typically a result of inadequate disinfection, mechanical failure, and insufficient technical expertise of system operators. ${ }^{33-35}$ A scoping review of drinking water quality and health outcomes of Canadian indigenous communities found various reports of adverse health outcomes (mostly GI) associated with drinking water but highlighted the paucity of relevant research. ${ }^{36}$ The remote, indigenous communities of Australia may also be at higher risk of 
medRxiv preprint doi: https://doi.org/10.1101/2022.03.03.22271862; this version posted March 6, 2022. The copyright holder for this preprint (which was not certified by peer review) is the author/funder, who has granted medRxiv a license to display the preprint in perpetuity.

All rights reserved. No reuse allowed without permission.

infection with waterborne pathogens. The water supply in many of these communities often fails to meet microbiological water quality standards, ${ }^{37}$ and Ng-Hublin et al. found that the notification rate of cryptosporidiosis in Aboriginal people was 50 times that among nonAboriginal people in Western Australia. ${ }^{38}$ Schaider et al. found a positive association across the United States between the proportion of Hispanic residents and nitrate levels in drinking water. ${ }^{39}$ Balasz et al. found a similar association in the San Joaquin Valley of California for small community water systems serving a large proportion of Latino residents. ${ }^{40}$ A study by Nigra and Navas-Acien found that incarcerated people in the southwestern US were disproportionately at risk of exposure to arsenic in drinking water. ${ }^{41}$ MacDonald Gibson et al. found that in Wake County, North Carolina (US), children in households relying on private wells had higher blood lead levels than those with community water service and that these differences were especially acute in peri-urban minority communities. ${ }^{42}$

\subsubsection{Limited Scope of Disease Types and Contaminants}

Nearly all the studies of the waterborne infectious disease burden consider only GI, overlooking other critical diseases (such as respiratory illnesses) that can be transmitted through drinking water. For example, only three studies identified in this review ${ }^{43-45}$ characterized the respiratory disease burden attributable to Legionella, even though it caused all deaths from waterborne disease outbreaks in the United States in 2013-2014. ${ }^{46}$

More information on the comparative disease burden from chemical contaminants is especially important for developed nations since these contaminants tend to be the major focus of drinking water regulations in developed nations. ${ }^{13,47}$ Especially notable is the dearth of studies estimating the disease burden from lead in drinking water, despite recent water crises brought about by lead (for example, in Flint, Michigan, US), along with mounting evidence that exposure to lead in private well water may be much more prevalent than previously recognized and, in some cases, can be a source of health disparities. ${ }^{42,48}$ This review located only one study that quantified the burden of disease due to lead in drinking water in a developed nation, and it was completed more than 20 years ago. This finding is surprising, since lead is ubiquitous in plumbing (even in plumbing branded as "lead-free"). ${ }^{49}$ Updated estimates of lead exposure risks from drinking water and the associated disease burden are needed across developed nations.

Also needed are studies of the disease burden attributable to "emerging" chemical contaminants - that is, those for which knowledge on their potential prevalence in drinking water is relatively new. One example is per- and polyfluoroalkyl substances (PFAS), which have been reported in drinking water sources and systems globally in recent years. ${ }^{50}$ Another example is toxins formed by aquatic fungi and algae, such as mycotoxins and cyanotoxins. ${ }^{51}$ The most recently published waterborne disease surveillance data from the US Centers for Disease Control and Prevention indicate that cyanotoxins caused $12 \%$ of reported US waterborne disease cases. ${ }^{46}$

\subsubsection{Insufficient Consideration of Causal Factors}

Also lacking is information that would enable estimates of specific water system deficiencies causing preventable illness. Available estimates focus on total disease burden, not on contributing factors. These might include source water contamination, treatment system deficiencies or failures, distribution system breaches, disinfectant loss in the distribution system, 
medRxiv preprint doi: https://doi.org/10.1101/2022.03.03.22271862; this version posted March 6, 2022. The copyright holder for this preprint (which was not certified by peer review) is the author/funder, who has granted medRxiv a license to display the preprint in perpetuity.

All rights reserved. No reuse allowed without permission.

water shutoffs and low-pressure events, or release or formation of contaminants as water travels through plumbing within buildings.

\section{Conclusions}

This review sheds light on the dearth of research on the disease burden attributable to unsafe drinking water in countries with high access to safe drinking water. Estimating this disease burden remains difficult given the lack of a comprehensive surveillance system and gaps in drinking water quality data. JMP data suggesting the vast majority of the population has access to safely managed water can be misleading because these data mask variation in the quality of water service delivery that can have important public health consequences. Further research on the drinking water-attributed disease burden in these countries remains vital to identifying the main drivers of waterborne disease, the populations at greatest risk, and strategies for improving health outcomes related to drinking water.

\section{Contributors}

HMM, JMG, and JB designed the study. DL, JH, JMG, and HMM recovered articles, assessed article eligibility, and extracted and analyzed data from articles. DL, JMG, and HMM wrote the initial drafts of the manuscript. All authors contributed to edits of the manuscript.

\section{Data sharing}

Extracted data are available on request to the corresponding author.

\section{Acknowledgements}

We would like to thank Jessica Evans, Ilya Law (IL), Tala Alahdab (TA) for their help screening titles and abstracts for this review.

\section{Funding}

JMG was supported in part by the U.S. National Science Foundation (CMMI-2017207). HMM, JH and IL were supported in part by the Canada Research Chairs Program (Grant \# 950-232787). DL was supported in part by Pennsylvania Department of Health's Pennsylvania Commonwealth Universal Research Enhancement Program (PA CURE) Formula Funds 2019 (Grant \# 4100083099 to Temple University). TA was supported in part by the University of Guelph's Undergraduate Research Assistant Program.

\section{Protocol Registration}

A protocol for this review was not formally registered.

\section{Competing Interests}

The authors have no competing interests to declare.

\section{References}

$1 \quad$ United Nations. UN-Water SDG 6 Data Portal. UN-Water SDG 6 Data Portal. .

2 Prüss-Ustün A, Wolf J, Bartram J, et al. Burden of disease from inadequate water, sanitation and hygiene for selected adverse health outcomes: An updated analysis with a focus on low- and middle-income countries. Int J Hyg Environ Health 2019; 222: 765-77.

3 Balazs CL, Ray I. The drinking water disparities framework: on the origins and 
medRxiv preprint doi: https://doi.org/10.1101/2022.03.03.22271862; this version posted March 6, 2022. The copyright holder for this preprint

persistence of inequities in exposure. Am J Public Health 2014; 104: 603-11.

4 Anderson MW. Cities inside out: race, poverty, and exclusion at the urban fringe. UCLA Law Rev 2008; 55: 1095-160.

5 Morris JC. Planning for Water Infrastructure: Challenges and Opportunities. Public Work Manag Policy 2017; 22: 24-30.

6 Page MJ, McKenzie JE, Bossuyt PM, et al. The PRISMA 2020 statement: An updated guideline for reporting systematic reviews. BMJ 2021; 372. DOI:10.1136/BMJ.N71.

7 Temkin A, Evans S, Manidis T, Campbell C, Naidenko O V. Exposure-based assessment and economic valuation of adverse birth outcomes and cancer risk due to nitrate in United States drinking water. Environ Res 2019; 176: 108442.

8 Mathewson PD, Evans S, Byrnes T, Joos A, Naidenko O V. Health and economic impact of nitrate pollution in drinking water: a Wisconsin case study. Environ Monit Assess 2020; 192: $1-18$.

9 de Hollander AEM, Melse JM, Lebret E, Kramers PGN. An aggregate public health indicator to represent the impact of multiple environmental exposures. EPIDEMIOLOGY 1999; 10: 606-17.

10 DeFelice NB, Leker HG, Gibson JM. Annual cancer risks from chemicals in North Carolina community water systems. Hum Ecol RISK Assess 2017; 23: 974-91.

11 Steenland K, Armstrong B. An overview of methods for calculating the burden of disease due to specific risk factors. Epidemiology 2006; 17: 512-9.

12 Colford Jr JM, Roy S, Beach MJ, Hightower A, Shaw SE, Wade TJ. A review of household drinking water intervention trials and an approach to the estimation of endemic waterborne gastroenteritis in the United States. J Water Health 2006; 4: 71-88.

13 DeFelice NB, Leker HG, MacDonald Gibson J. Annual cancer risks from chemicals in North Carolina community water systems. Hum Ecol Risk Assess 2017; 23: 974-91.

14 Gibney KB, O'Toole J, Sinclair M, Leder K. Burden of Disease Attributed to Waterborne Transmission of Selected Enteric Pathogens, Australia, 2010. Am J Trop Med Hyg 2017; 96: 1400-3.

15 DeFelice NB, Johnston JE, Gibson JM. Reducing Emergency Department Visits for Acute Gastrointestinal Illnesses in North Carolina (USA) by Extending Community Water Service. Environ Health Perspect 2016; 124: 1583-91.

16 DeFelice NB, Johnston JE, MacDonald Gibson J. Acute gastrointestinal illness risks in North Carolina community water Systems: a methodological comparison. Environ Sci Technol 2015; 49: 10019-27.

17 Murphy HM, Pintar KDM, McBean EA, Thomas MK. A systematic review of waterborne disease burden methodologies from developed countries. J Water Health 2014; 12: 63455 .

18 Murphy HM, Thomas MK, Schmidt PJ, Medeiros DT, McFadyen S, Pintar KDM. Estimating the burden of acute gastrointestinal illness due to Giardia, Cryptosporidium, Campylobacter, E. coli $\mathrm{O} 157$ and norovirus associated with private wells and small water systems in Canada. Epidemiol Infect 2016; 144: 1355-70.

19 Burch TR, Stokdyk JP, Spencer SK, et al. Quantitative Microbial Risk Assessment for Contaminated Private Wells in the Fractured Dolomite Aquifer of Kewaunee County, Wisconsin. Environ Health Perspect 2021; 129. DOI:10.1289/EHP7815.

20 Reynolds K, D Mena K, Gerba C. Risk of Waterborne Illness Via Drinking Water in the United States. 2008 DOI:10.1007/978-0-387-71724-1_4. 
medRxiv preprint doi: https://doi.org/10.1101/2022.03.03.22271862; this version posted March 6, 2022. The copyright holder for this preprint

21 Abtahi M, Dobaradaran S, Jorfi S, et al. Age-sex specific disability-adjusted life years (DALYs) attributable to elevated levels of fluoride in drinking water: A national and subnational study in Iran, 2017. WATER Res 2019; 157: 94-105.

22 Dobaradaran S, Fard ES, Tekle-Rottering A, et al. Age-sex specific and cause-specific health risk and burden of disease induced by exposure to trihalomethanes (THMs) and haloacetic acids (HAAs) from drinking water: An assessment in four urban communities of Bushehr Province, Iran, 2017. Environ Res 2020; 182.

DOI:10.1016/j.envres.2019.109062.

23 Greco SL, Belova A, Haskell J, Backer L. Estimated burden of disease from arsenic in drinking water supplied by domestic wells in the United States. J Water Health 2019; 17: 801-12.

24 World Health Organisation. Guidelines for drinking-water quality, 4th edition: 1st addendum. WHO, 2017.

25 GBD 2019 Resources | Institute for Health Metrics and Evaluation. .

26 Salomon JA, Haagsma JA, Davis A, et al. Disability weights for the Global Burden of Disease 2013 study. Lancet Glob Heal 2015; 3: e712-23.

27 Haass JA, Miller GL, Haddix AC, Nickey LN, Sinks T. An economic analysis of water and sanitation infrastructure improvements in the Colonias of EI Paso County, Texas. Int J Occup Environ Health 1996; 2: 211-21.

28 Beaudeau P, Schwartz J, Levin R. Drinking water quality. and hospital admissions of elderly people for gastrointestinal illness in Eastern Massachusetts, 1998-2008. WATER Res 2014; 52: 188-98.

29 Allaire M, Wu H, Lall U. National trends in drinking water quality violations. Proc Natl Acad Sci U S A 2018; 115: 2078-83.

30 Cretikos M, Byleveld P, Durrheim DN, Porigneaux P, Merritt T, Leask S. Supply system factors associated with microbiological drinking water safety in regional New South Wales, Australia, 2001-2007. J Water Health 2009; 8: 257-68.

31 McFarlane K, Harris LM. Small systems, big challenges: review of small drinking water system governance. Environ Rev 2018; 26: 378+.

32 Stauber CE, Wedgworth JC, Johnson P, et al. Associations between Self-Reported Gastrointestinal Illness and Water System Characteristics in Community Water Supplies in Rural Alabama: A Cross-Sectional Study. PLoS One 2016; 11.

DOI:10.1371/journal.pone.0148102.

33 Murphy HM, Bhatti M, Harvey R, McBean EA. Using Decision Trees to Predict Drinking Water Advisories in Small Water Systems. J AWWA 2016; 108: E109-18.

34 Murphy HM, Corston-Pine E, Post Y, McBean EA. Insights and opportunities: challenges of Canadian First Nations drinking water operators. Int Indig Policy J 2015; 6.

35 Lui E. On notice for a drinking water crisis in Canada. Council of Canadians Ottawa, 2015.

36 Bradford LEA, Bharadwaj LA, Okpalauwaekwe U, Waldner CL. Drinking water quality in Indigenous communities in Canada and health outcomes: a scoping review. Int $J$ Circumpolar Health 2016; 75. DOI:10.3402/ijch.v75.32336.

37 OAG. Delivering Essential Services to Remote Aboriginal Communities. 2015.

38 Ng-Hublin JSY, Combs B, Reid S, Ryan U. Differences in the occurrence and epidemiology of cryptosporidiosis in Aboriginal and non-Aboriginal people in Western Australia (2002-2012). Infect Genet Evol 2017; 53: 100-6. 
medRxiv preprint doi: https://doi.org/10.1101/2022.03.03.22271862; this version posted March 6, 2022. The copyright holder for this preprint (which was not certified by peer review) is the author/funder, who has granted medRxiv a license to display the preprint in perpetuity.

All rights reserved. No reuse allowed without permission.

39 Schaider LA, Swetschinski L, Campbell C, Rudel RA. Environmental justice and drinking water quality: are there socioeconomic disparities in nitrate levels in U.S. drinking water? Environ Heal 2019; 18: 3.

40 Balazs C, Morello-Frosch R, Hubbard A, Ray I. Social disparities in nitrate-contaminated drinking water in California's San Joaquin Valley. Environ Health Perspect 2011; 119: 1272-8.

41 Nigra AE, Navas-Acien A. Arsenic in US correctional facility drinking water, 2006-2011. Environ Res 2020; 188: 109768.

42 MacDonald Gibson J, Fisher M, Clonch A, MacDonald J, Cook P. Children drinking private well water have higher blood lead than those with city water. Proc Natl Acad Sci 2020; 117: 16898-907.

43 Vinson NG. Towards estimating the economic burden of waterborne illness in Canada: what do we know, where do we go. In: Poster presented at The Ontario Public Health Convention (TOPHC), Toronto, ON, Canada. 2012: 2-4.

44 Verhougstraete M, Reynolds KA, Pearce-Walker J, Gerba C. Cost-benefit analysis of point-of-use devices for health risks reduction from pathogens in drinking water. $J$ Water Health 2020; 18: 968-82.

45 Collier SA, Deng L, Adam EA, et al. Estimate of burden and direct healthcare cost of infectious waterborne disease in the United States. 2020.

46 Benedict KM, Reses H, Vigar M, et al. Surveillance for Waterborne Disease Outbreaks Associated with Drinking Water — United States, 2013-2014. MMWR Morb Mortal Wkly Rep 2017; 66: 1216-21.

47 Roberson JA. What's next after 40 years of drinking water regulations? Environ Sci Technol 2011; 45: 154-60.

48 Hanna-Attisha M, LaChance J, Sadler RC, Schnepp AC. Elevated blood lead levels in children associated with the Flint drinking water crisis: A spatial analysis of risk and public health response. Am J Public Health 2016; 106: 283-90.

49 Katner A, Pieper KJ, Lambrinidou Y, et al. Weaknesses in Federal Drinking Water Regulations and Public Health Policies that Impede Lead Poisoning Prevention and Environmental Justice. Environ Justice 2016; 9: 109-17.

50 Domingo JL, Nadal M. Human exposure to per- and polyfluoroalkyl substances (PFAS) through drinking water: A review of the recent scientific literature. Environ Res 2019; 177: 108648.

51 Székács A. Mycotoxins as emerging contaminants. Introduction to the special issue "rapid detection of mycotoxin contamination”. Toxins (Basel). 2021; 13.

DOI:10.3390/toxins13070475.

52 Ball A. Estimation of the burden of water-borne disease in New Zealand: preliminary report. Christchurch Environ Sci Res Ltd 2006.

53 Burch TR, Stokdyk JP, Spencer SK, et al. Quantitative Microbial Risk Assessment for Contaminated Private Wells in the Fractured Dolomite Aquifer of Kewaunee County, Wisconsin. Environ Health Perspect 2021; 129. DOI:10.1289/EHP7815.

54 Butler AJ, Pintar KDM, Thomas MK. Estimating the Relative Role of Various Subcategories of Food, Water, and Animal Contact Transmission of 28 Enteric Diseases in Canada. Foodborne Pathog Dis 2016; 13: 57-64.

55 DeFelice NB, Johnston JE, Gibson JM. Acute Gastrointestinal Illness Risks in North Carolina Community Water Systems: A Methodological Comparison. Environ Sci 
medRxiv preprint doi: https://doi.org/10.1101/2022.03.03.22271862; this version posted March 6, 2022. The copyright holder for this preprint

(which was not certified by peer review) is the author/funder, who has granted medRxiv a license to display the preprint in perpetuity.

All rights reserved. No reuse allowed without permission.

Technol 2015; 49: 10019-27.

56 Eisenberg JNS, Hubbard A, Wade TJ, et al. Inferences Drawn from a Risk Assessment Compared Directly with a Randomized Trial of a Home Drinking Water Intervention. Environ Health Perspect 2006; 114: 1199-204.

57 Kim JH, Cheong HK, Jeon BH. Burden of Disease Attributable to Inadequate Drinking Water, Sanitation, and Hygiene in Korea. J KOREAN Med Sci 2018; 33.

DOI:10.3346/jkms.2018.33.e288.

58 MacDonald Gibson J, Thomsen J, Launay F, Harder E, DeFelice N. Deaths and medical visits attributable to environmental pollution in the United Arab Emirates. PLoS One 2013; 8: e57536-e57536.

59 Masciopinto C, De Giglio O, Scrascia M, et al. Human health risk assessment for the occurrence of enteric viruses in drinking water from wells: Role of flood runoff injections. Sci Total Environ 2019; 666: 559-71.

60 Messner M, Shaw S, Regli S, Rotert K, Blank V, Soller J. An approach for developing a national estimate of waterborne disease due to drinking water and a national estimate model application. J Water Health 2006; 4: 201-40.

61 Moore D, Black M, Valji Y, Tooth R. Cost Benefit Analysis of Raising the Quality of New Zealand Networked Drinking Water. 2010 http://srgexpert.com/wpcontent/uploads/2018/02/cba-raising-quality-of-networked-drinking-water-jun20101.pdf.

62 Morris RD, Levin R. Estimating the incidence of waterborne infectious disease related to drinking water in the United States. IAHS Publ Proc Reports-Intern Assoc Hydrol Sci 1995; 233: 75-88.

63 Murphy HM, Thomas MK, Medeiros DT, McFadyen S, Pintar KDM. Estimating the number of cases of acute gastrointestinal illness (AGI) associated with Canadian municipal drinking water systems. Epidemiol Infect 2016; 144: 1371-85.

64 Payment P. Epidemiology of endemic gastrointestinal and respiratory diseases: Incidence, fraction attributable to tap water and costs to society. WATER Sci Technol 1997; 35: 7-10.

65 Perz JF, Ennever FK, Le Blancq SM. Cryptosporidium in Tap Water: Comparison of Predicted Risks with Observed Levels of Disease. Am J Epidemiol 1998; 147: 289-301.

66 Evlampidou I, Font-Ribera L, Rojas-Rueda D, et al. Trihalomethanes in Drinking Water and Bladder Cancer Burden in the European Union. Environ Health Perspect 2020; 128. DOI:10.1289/EHP4495.

67 Fewtrell L, Smith S, Kay D, Bartram J. An attempt to estimate the global burden of disease due to fluoride in drinking water. J Water Health 2006; 4: 533-42. 
Table 1. Estimated disease burden from waterborne microbial contaminants in high-income countries

\begin{tabular}{|c|c|c|c|c|c|c|c|}
\hline Author & Date & Location & Health Outcomes & $\begin{array}{l}\text { Exposure } \\
\text { Source }\end{array}$ & Pathogens & Approach & $\begin{array}{l}\text { Burden Estimate (Per } \\
\text { Year) }\end{array}$ \\
\hline Ball et al. ${ }^{52}$ & 2006 & New Zealand & Gl cases & Drinking & Unspecified & Top down & $33,743 \mathrm{GI}$ cases \\
\hline $\begin{array}{l}\text { Beaudeau et } \\
\text { al. }^{28}\end{array}$ & 2014 & $\begin{array}{l}\text { Boston, } \\
\text { Massachusetts, } \\
\text { USA }\end{array}$ & $\begin{array}{l}\text { Gl hospital } \\
\text { admissions }\end{array}$ & $\begin{array}{l}\text { Drinking (public } \\
\text { systems) }\end{array}$ & Unspecified & Top down & $\begin{array}{l}153 \mathrm{GI} \text { hospital } \\
\text { admissions }\end{array}$ \\
\hline Burch et al. ${ }^{53}$ & 2021 & $\begin{array}{l}\text { Kewaunee } \\
\text { County, } \\
\text { Wisconsin, USA }\end{array}$ & Gl cases & $\begin{array}{l}\text { Drinking (private } \\
\text { wells) }\end{array}$ & $\begin{array}{l}\text { Adenovirus group A, } \\
\text { Campylobacter, } \\
\text { Cryptosporidium, } \\
\text { enteropathogenic E. } \\
\text { coli, Giardia, } \\
\text { Salmonella }\end{array}$ & Bottom up & $301 \mathrm{Gl}$ cases \\
\hline Butler et al. ${ }^{54}$ & 2016 & Canada & $\begin{array}{l}\text { Enteric illness } \\
\text { cases }\end{array}$ & $\begin{array}{l}\text { Food, drinking, } \\
\text { recreation, } \\
\text { animal contact }\end{array}$ & $\begin{array}{l}\text { Campylobacter, } \\
\text { Cryptosporidium, } \\
\text { Giardia, verotoxin- } \\
\text { producing E. coli (non- } \\
\text { O157 and O157) }\end{array}$ & Top down & $\begin{array}{l}\text { 447,459 enteric illness } \\
\text { cases attributed to only } \\
\text { drinking water (private } \\
\text { wells, public water } \\
\text { systems, bottled) }\end{array}$ \\
\hline Colford et al. ${ }^{12}$ & 2006 & USA & Gl cases & $\begin{array}{l}\text { Drinking (public } \\
\text { systems) }\end{array}$ & Unspecified & Top down & $\begin{array}{l}4.26-11.69 \text { million } \mathrm{GI} \\
\text { cases }\end{array}$ \\
\hline Collier et al. ${ }^{45}$ & 2021 & USA & $\begin{array}{l}\text { GI and respiratory } \\
\text { cases, ED visits, } \\
\text { hospitalizations, } \\
\text { deaths }\end{array}$ & $\begin{array}{l}\text { Drinking, } \\
\text { recreation, } \\
\text { inhalation }\end{array}$ & $\begin{array}{l}\text { Campylobacter, } \\
\text { Cryptosporidium, } \\
\text { Giardia, Legionella, } \\
\text { nontuberculous } \\
\text { mycobacteria, } \\
\text { norovirus, } \\
\text { Pseudomonas, } \\
\text { Salmonella, Shiga } \\
\text { toxin-producing E. coli, } \\
\text { Shigella, Vibrio, } \\
\text { unspecified otitis } \\
\text { externa }\end{array}$ & Top down & $\begin{array}{l}7.15 \text { million waterborne } \\
\text { illnesses, } 601,000 \text { ED } \\
\text { visits, } 118,000 \\
\text { hospitalizations, } 6,630 \\
\text { deaths }\end{array}$ \\
\hline DeFelice et al. ${ }^{15}$ & 2016 & $\begin{array}{l}\text { North Carolina, } \\
\text { USA }\end{array}$ & ED visits for $\mathrm{Gl}$ & $\begin{array}{l}\text { Drinking (public } \\
\text { systems and } \\
\text { private wells) }\end{array}$ & Unspecified & Top down & 29,400 ED visits \\
\hline DeFelice et al. ${ }^{55}$ & 2015 & $\begin{array}{l}\text { North Carolina, } \\
\text { USA }\end{array}$ & ED visits for $\mathrm{Gl}$ & Drinking & $\begin{array}{l}\text { Giardia, } \\
\text { Campylobacter, } \\
\text { rotavirus }\end{array}$ & $\begin{array}{l}\text { Top down, } \\
\text { bottom up } \\
\text { comparison } \\
\end{array}$ & $\begin{array}{l}\text { Varied by approach: } \\
190,190, \text { and } 32,000 \\
\text { ED visits }\end{array}$ \\
\hline $\begin{array}{l}\text { Eisenberg et } \\
\text { al. }^{56}\end{array}$ & 2006 & lowa, USA & Gl cases & $\begin{array}{l}\text { Drinking (public } \\
\text { systems) }\end{array}$ & $\begin{array}{l}\text { Burden from trial data: } \\
\text { unspecified }\end{array}$ & $\begin{array}{l}\text { Top down, } \\
\text { bottom up } \\
\text { comparison }\end{array}$ & $\begin{array}{l}\text { Burden from trial data: } \\
1,825 \text { cases per } \\
10,000 \text { population }\end{array}$ \\
\hline
\end{tabular}




\begin{tabular}{|c|c|c|c|c|c|c|c|}
\hline Author & Date & Location & Health Outcomes & $\begin{array}{l}\text { Exposure } \\
\text { Source }\end{array}$ & Pathogens & Approach & $\begin{array}{l}\text { Burden Estimate (Per } \\
\text { Year) }\end{array}$ \\
\hline & & & & & $\begin{array}{l}\text { Burden from risk } \\
\text { model: Giardia, } \\
\text { Cryptosporidium, } \\
\text { unspecified viruses }\end{array}$ & & $\begin{array}{l}\text { Burden from risk } \\
\text { model: } 13.9 \text { cases per } \\
10,000 \text { population }\end{array}$ \\
\hline Gibney et al. ${ }^{14}$ & 2017 & Australia & $\begin{array}{l}\text { GI cases, deaths, } \\
\text { DALYs }\end{array}$ & $\begin{array}{l}\text { Drinking, } \\
\text { recreation }\end{array}$ & $\begin{array}{l}\text { Campylobacter, } \\
\text { Cryptosporidium, } \\
\text { Giardia, nontyphoidal } \\
\text { Salmonella, norovirus }\end{array}$ & Top down & $\begin{array}{l}\text { 820,003 GI cases; } 11 \\
\text { deaths }\end{array}$ \\
\hline Haass et al. ${ }^{27}$ & 1996 & $\begin{array}{l}\text { San Elizario, El } \\
\text { Paso County, } \\
\text { Texas, USA }\end{array}$ & $\begin{array}{l}\text { Gl cases, Hepatitis } \\
\text { A cases }\end{array}$ & $\begin{array}{l}\text { Drinking, } \\
\text { sanitation }\end{array}$ & $\begin{array}{l}\text { Entamoeba histolytica, } \\
\text { Campylobacter, } \\
\text { hepatitis A virus, } \\
\text { nontyphoidal } \\
\text { Salmonella, typhoidal } \\
\text { Salmonella, Shigella }\end{array}$ & Top down & $\begin{array}{l}199 \mathrm{Gl} \text { cases, } 6 \\
\text { hepatitis A cases }\end{array}$ \\
\hline Kim et al. ${ }^{57}$ & 2018 & Korea & Deaths, DALYs & $\begin{array}{l}\text { Drinking, } \\
\text { sanitation, } \\
\text { hygiene }\end{array}$ & $\begin{array}{l}\text { Unspecified GI } \\
\text { pathogens (includes } \\
\text { hepatitis A virus and } \\
\text { helminths) }\end{array}$ & Top down & 6 deaths \\
\hline $\begin{array}{l}\text { MacDonald } \\
\text { Gibson et al. }{ }^{58}\end{array}$ & 2013 & $\begin{array}{l}\text { United Arab } \\
\text { Emirates }\end{array}$ & $\begin{array}{l}\text { Gastroenteritis } \\
\text { cases }\end{array}$ & Drinking & Unspecified & Top down & $\begin{array}{l}46,200 \text { cases ( } 4 \\
\text { deaths) }\end{array}$ \\
\hline $\begin{array}{l}\text { Masciopinto et } \\
\text { al. }^{59}\end{array}$ & 2019 & $\begin{array}{l}\text { Salento Region, } \\
\text { Italy }\end{array}$ & $\begin{array}{l}\text { Gl cases, hepatitis } \\
\text { A, DALYs }\end{array}$ & $\begin{array}{l}\text { Drinking } \\
\text { (groundwater) }\end{array}$ & $\begin{array}{l}\text { Adenovirus, } \\
\text { enterovirus, hepatitis A } \\
\text { virus, norovirus, } \\
\text { rotavirus }\end{array}$ & Bottom up & $\begin{array}{l}348 \mathrm{Gl} \text { cases; } 2 \\
\text { hepatitis A cases } \\
\text { (summer only) }\end{array}$ \\
\hline Messner et al..$^{60}$ & 2006 & USA & AGI cases & Drinking & Unspecified & Top down & 16.4 million cases \\
\hline Moore et al. ${ }^{61}$ & 2010 & New Zealand & AGI cases & $\begin{array}{l}\text { Drinking } \\
\text { (noncompliant } \\
\text { public systems) }\end{array}$ & Unspecified & Top down & 35,000 cases \\
\hline $\begin{array}{l}\text { Morris and } \\
\text { Levin }^{62}\end{array}$ & 1995 & USA & GI cases, deaths & Drinking & $\begin{array}{l}\text { Campylobacter, } \\
\text { Cryptosporidium, E. } \\
\text { coli, Giardia, norovirus } \\
\text { Salmonella, Shigella }\end{array}$ & $\begin{array}{l}\text { Top down } \\
\text { (bacteria); } \\
\text { bottom up } \\
\text { (parasites \& } \\
\text { viruses) }\end{array}$ & $\begin{array}{l}7.66 \text { million cases; } \\
1,210 \text { deaths }\end{array}$ \\
\hline Murphy et al. ${ }^{63}$ & 2016 & Canada & AGI cases & $\begin{array}{l}\text { Drinking (public } \\
\text { systems serving } \\
>1,000 \text { ) }\end{array}$ & Unspecified & Top down & 334,966 cases \\
\hline Murphy et al. ${ }^{18}$ & 2016 & Canada & AGI cases & $\begin{array}{l}\text { Drinking (private } \\
\text { wells, small } \\
\text { public systems) }\end{array}$ & $\begin{array}{l}\text { Campylobacter, } \\
\text { Cryptosporidium, E. } \\
\text { coli O157:H7, Giardia, } \\
\text { norovirus }\end{array}$ & Bottom up & 103,230 cases \\
\hline
\end{tabular}




\begin{tabular}{|c|c|c|c|c|c|c|c|}
\hline Author & Date & Location & Health Outcomes & $\begin{array}{l}\text { Exposure } \\
\text { Source }\end{array}$ & Pathogens & Approach & $\begin{array}{l}\text { Burden Estimate (Per } \\
\text { Year) }\end{array}$ \\
\hline Payment $^{64}$ & 1997 & Canada & HCGI cases & $\begin{array}{l}\text { Drinking (public } \\
\text { systems) }\end{array}$ & Unspecified & Top down & $4,200,000$ \\
\hline Perz et al. ${ }^{65}$ & 1998 & $\begin{array}{l}\text { New York City, } \\
\text { USA }\end{array}$ & Gl cases & $\begin{array}{l}\text { Drinking (public } \\
\text { systems) }\end{array}$ & Cryptosporidium & Bottom up & 42 cases \\
\hline $\begin{array}{l}\text { Reynolds et } \\
\text { al. }^{20}\end{array}$ & 2008 & USA & Gl cases & $\begin{array}{l}\text { Drinking (public } \\
\text { systems) }\end{array}$ & $\begin{array}{l}\text { Campylobacter, } \\
\text { Cryptosporidium, and } \\
\text { rotavirus (and other } \\
\text { unspecified viruses) }\end{array}$ & Bottom up & 19.5 million cases \\
\hline $\begin{array}{l}\text { Verhougstraete } \\
\text { et al. } 44\end{array}$ & 2020 & USA & $\begin{array}{l}\text { GI cases, } \\
\text { Legionnaires' } \\
\text { disease, sequela } \\
\text { and mortality }\end{array}$ & Drinking & $\begin{array}{l}\text { Adenovirus, } \\
\text { Campylobacter, } \\
\text { Cryptosporidium } \\
\text { Salmonella, E. coli } \\
\text { O157:H7, Giardia, } \\
\text { hepatitis A virus, } \\
\text { Legionella, norovirus, } \\
\text { and rotavirus }\end{array}$ & Top down & $\begin{array}{l}9 \text { million GI cases; } \\
\text { 13,000 Legionnaire's } \\
\text { disease cases; } 32,531 \\
\text { Hepatitis A cases; } 0.6 \\
\text { million sequela; } 1,470 \\
\text { GI deaths }\end{array}$ \\
\hline Vinson $^{43}$ & 2012 & Canada & $\begin{array}{l}\text { Gl cases, } \\
\text { respiratory } \\
\text { diseases, } \\
\text { toxoplasmosis, ear } \\
\text { infections }\end{array}$ & $\begin{array}{l}\text { Drinking, } \\
\text { recreation, } \\
\text { inhalation }\end{array}$ & $\begin{array}{l}\text { Legionella } \\
\text { pneumophila, } \\
\text { Mycoplasma } \\
\text { pneumoniae, } \\
\text { Toxoplasma gondii and } \\
\text { unspecified pathogens } \\
\text { causing Gl/otitis } \\
\text { externa, }\end{array}$ & Top down & 1.32 million $\mathrm{Gl}$ cases \\
\hline
\end{tabular}

GI- Gastrointestinal illness

AGI- Acute gastrointestinal illness

HCGl- Highly credible gastrointestinal illness

ED- Emergency department

DALYs- Disability Adjusted Life Years 
Table 2. Estimated disease burden from waterborne chemical contaminants in high-income countries

\begin{tabular}{|c|c|c|c|c|c|c|c|}
\hline Author & Date & Location & Health Outcomes & $\begin{array}{l}\text { Exposure } \\
\text { Source }\end{array}$ & $\begin{array}{l}\text { Chemical } \\
\text { Contaminant }\end{array}$ & Approach & Burden Estimate (Per Year) \\
\hline Abtahi et al. ${ }^{21}$ & 2019 & Iran & Dental fluorosis & Drinking & Fluoride & Bottom up & $\begin{array}{l}60 \text { cases } / 100,000 \text { people }(95 \% \mathrm{Cl} 48- \\
69)\end{array}$ \\
\hline $\begin{array}{l}\text { de Hollander et } \\
\text { al. }^{9}\end{array}$ & 1999 & The Netherlands & $\begin{array}{l}\text { Loss of } 1-3 \mathrm{IQ} \\
\text { points }\end{array}$ & Drinking & Lead & Bottom up & 1,764 cases \\
\hline $\begin{array}{l}\text { DeFelice et } \\
\text { al. }{ }^{13}\end{array}$ & 2017 & $\begin{array}{l}\text { North Carolina, } \\
\text { USA }\end{array}$ & Cancer & $\begin{array}{l}\text { Drinking } \\
\text { (public } \\
\text { systems) } \\
\end{array}$ & 20 carcinogens & Top down & $\begin{array}{l}53.9(95 \% \mathrm{Cl} 27.8-79.4) \text { deaths } \\
\text { statewide; individual risk } 7.2 \times 10^{-6}\end{array}$ \\
\hline $\begin{array}{l}\text { Dobaradaran et } \\
\text { al. }{ }^{22}\end{array}$ & 2020 & $\begin{array}{l}\text { Bushehr } \\
\text { Province, } \\
\text { Iran }\end{array}$ & Cancer & $\begin{array}{l}\text { Drinking, } \\
\text { dermal, } \\
\text { inhalation }\end{array}$ & $\begin{array}{l}\text { Disinfection } \\
\text { byproducts }\end{array}$ & Bottom up & $\begin{array}{l}1(95 \% \mathrm{Cl} 0.32-2.8) \text { death in Bushehr } \\
\text { Province; 95.0 DALYs (94.7-95.2). }\end{array}$ \\
\hline $\begin{array}{l}\text { Evlampidou et } \\
\text { al. }{ }^{66}\end{array}$ & 2020 & $\begin{array}{l}28 \text { European } \\
\text { Union countries }\end{array}$ & Cancer & Drinking & $\begin{array}{l}\text { Disinfection } \\
\text { byproducts }\end{array}$ & Top down & $\begin{array}{l}6,561(95 \% \mathrm{Cl} 3,389,9,537) \text { cases } \\
\text { across the } \mathrm{EU}\end{array}$ \\
\hline Fewtrell et al. ${ }^{67}$ & 2006 & $\begin{array}{l}\text { USA, United } \\
\text { Kingdom, New } \\
\text { Zealand }\end{array}$ & $\begin{array}{l}\text { Dental and skeletal } \\
\text { fluorosis }\end{array}$ & Drinking & Fluoride & Bottom up & Zero \\
\hline Greco et al. ${ }^{23}$ & 2019 & USA & $\begin{array}{l}\text { Ischemic heart } \\
\text { disease; cancer }\end{array}$ & $\begin{array}{l}\text { Drinking } \\
\text { (private } \\
\text { wells) } \\
\end{array}$ & Arsenic & Bottom up & $\begin{array}{l}500 \text { ischemic heart disease deaths; } 496 \\
\text { fatal cancer cases; } 578 \text { nonfatal cancer } \\
\text { cases }\end{array}$ \\
\hline $\begin{array}{l}\text { MacDonald } \\
\text { Gibson et al. }{ }^{58}\end{array}$ & 2013 & $\begin{array}{l}\text { United Arab } \\
\text { Emirates }\end{array}$ & $\begin{array}{l}\text { Bladder and } \\
\text { colorectal cancers }\end{array}$ & Drinking & $\begin{array}{l}\text { Trihalomethanes } \\
\text { (THMs) }\end{array}$ & Top down & $\begin{array}{l}154 \text { healthcare facility visits (and } 3 \\
\text { deaths) for bladder cancers and } 328 \\
\text { visits (and } 9 \text { deaths) for colorectal } \\
\text { cancers }\end{array}$ \\
\hline $\begin{array}{l}\text { Mathewson et } \\
\text { al. }^{8}\end{array}$ & 2020 & Wisconsin, USA & $\begin{array}{l}\text { Cancer; neural tube } \\
\text { defects; low birth } \\
\text { weight; preterm } \\
\text { birth }\end{array}$ & Drinking & Nitrate & Top down & $\begin{array}{l}95 \text { (range } 46-149 \text { very low birth weight } \\
\text { babies; } 51 \text { (range } 26-79 \text { ) very preterm } \\
\text { births; } 1-2 \text { neural tube defect births; } 169 \\
\text { (range } 111-297 \text { ) cancer cases }\end{array}$ \\
\hline Temkin et al. $^{7}$ & 2019 & USA & $\begin{array}{l}\text { Cancer; neural tube } \\
\text { defects; low birth } \\
\text { weight; preterm } \\
\text { birth }\end{array}$ & Drinking & Nitrate & Top down & $\begin{array}{l}2,939 \text { very low birth weight cases; } 1,725 \\
\text { very preterm births; } 41 \text { neural tube } \\
\text { defect births; } 6,537 \text { (range } 2,300- \\
12,594 \text { ) cancer cases }\end{array}$ \\
\hline
\end{tabular}




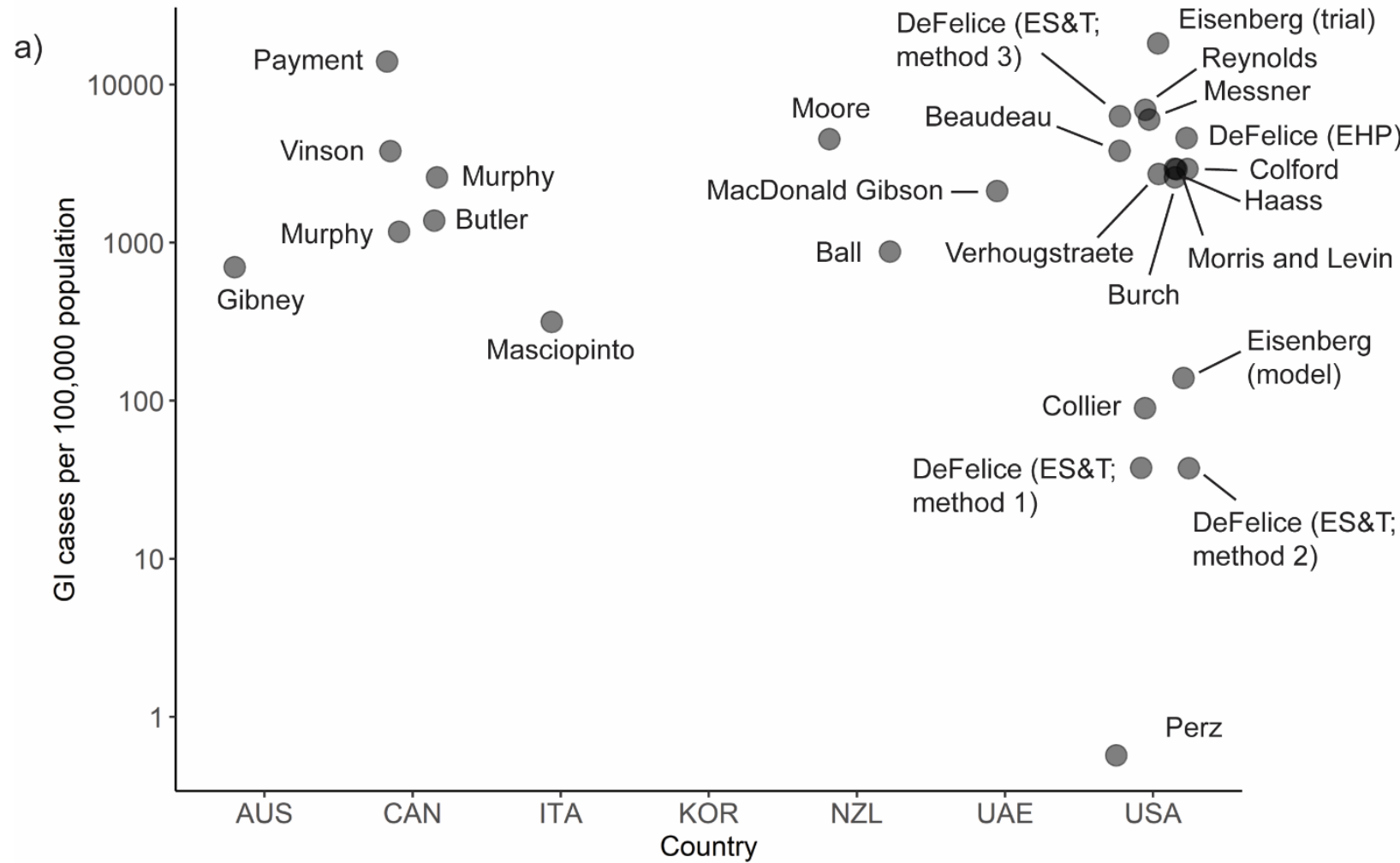

b)

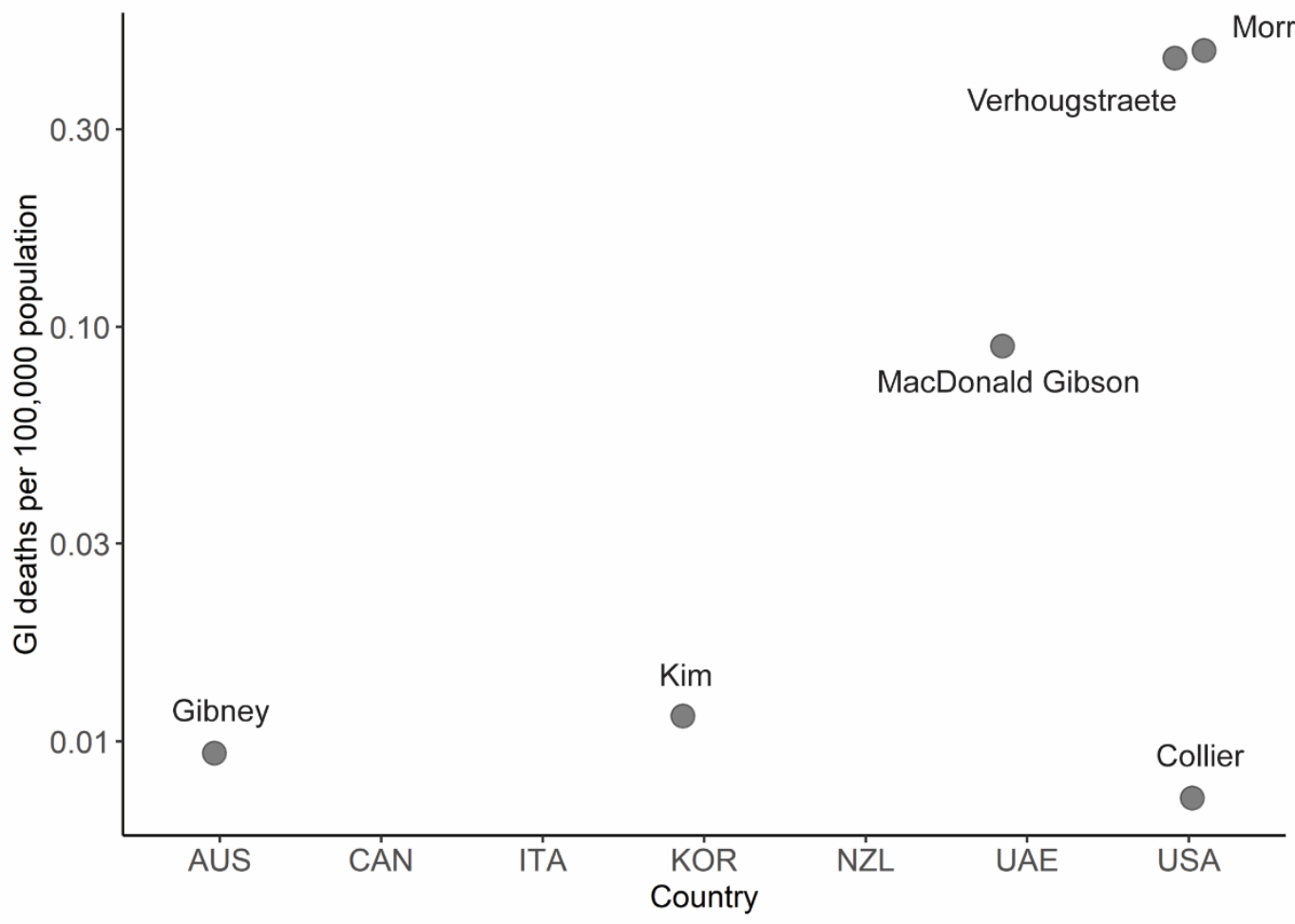

Figure 1. Summary of burden estimates (incidence per 100,000 population) for a) cases of GI illness attributed to microbiological contamination of drinking water and b) deaths from illness attributed to microbiological contamination of drinking water.

Countries: AUS=Australia, CAN=Canada, ITA=Italy, KOR=Republic of Korea, NZL=New Zealand, UAE=United Arab Emirates, USA=United States of America 


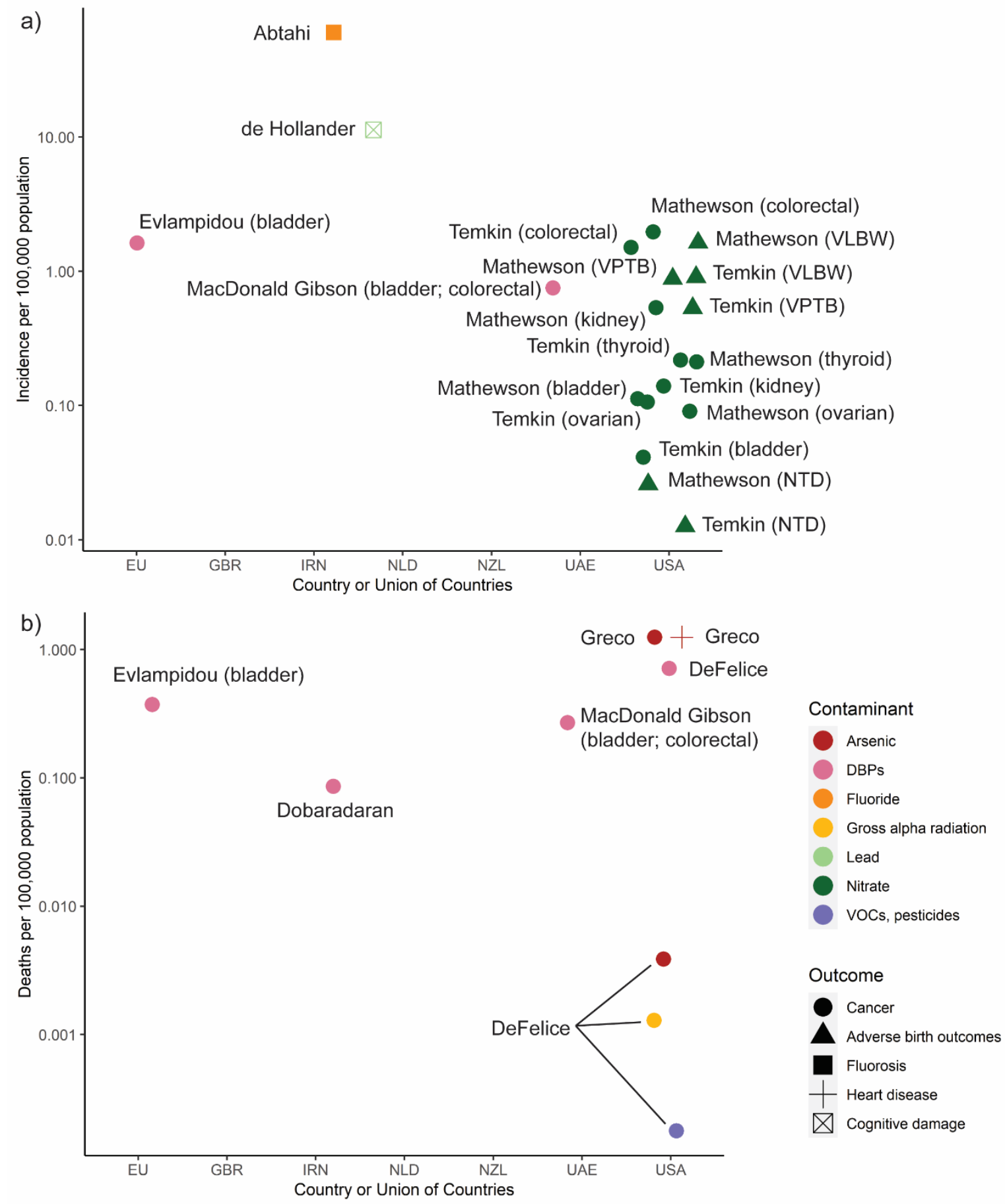

Figure 2. Summary of burden estimates (incidence per 100,000 population) for a) cases of illness attributed to chemical contamination of drinking water, and $b$ ) deaths from illness attributed to chemical contamination of drinking water.

Note: Estimates of zero cases (per 100,000 population) of fluorosis in USA, GBR (UK), NZL by Fewtrell et al. were excluded

Countries: EU=European Union, GBR=United Kingdom, IRN=Iran, NLD=The Netherlands, UAE=United Arab Emirates, USA=United States of America Contaminants: DBPs=Disinfection by-products, VOCs=Volatile Organic Compounds Outcomes: VLBW=Very low birth weight, VPTB=Very preterm birth, NTD=Neural tube defects 
medRxiv preprint doi: https://doi.org/10.1101/2022.03.03.22271862; this version posted March 6, 2022. The copyright holder for this preprint (which was not certified by peer review) is the author/funder, who has granted medRxiv a license to display the preprint in perpetuity. All rights reserved. No reuse allowed without permission.
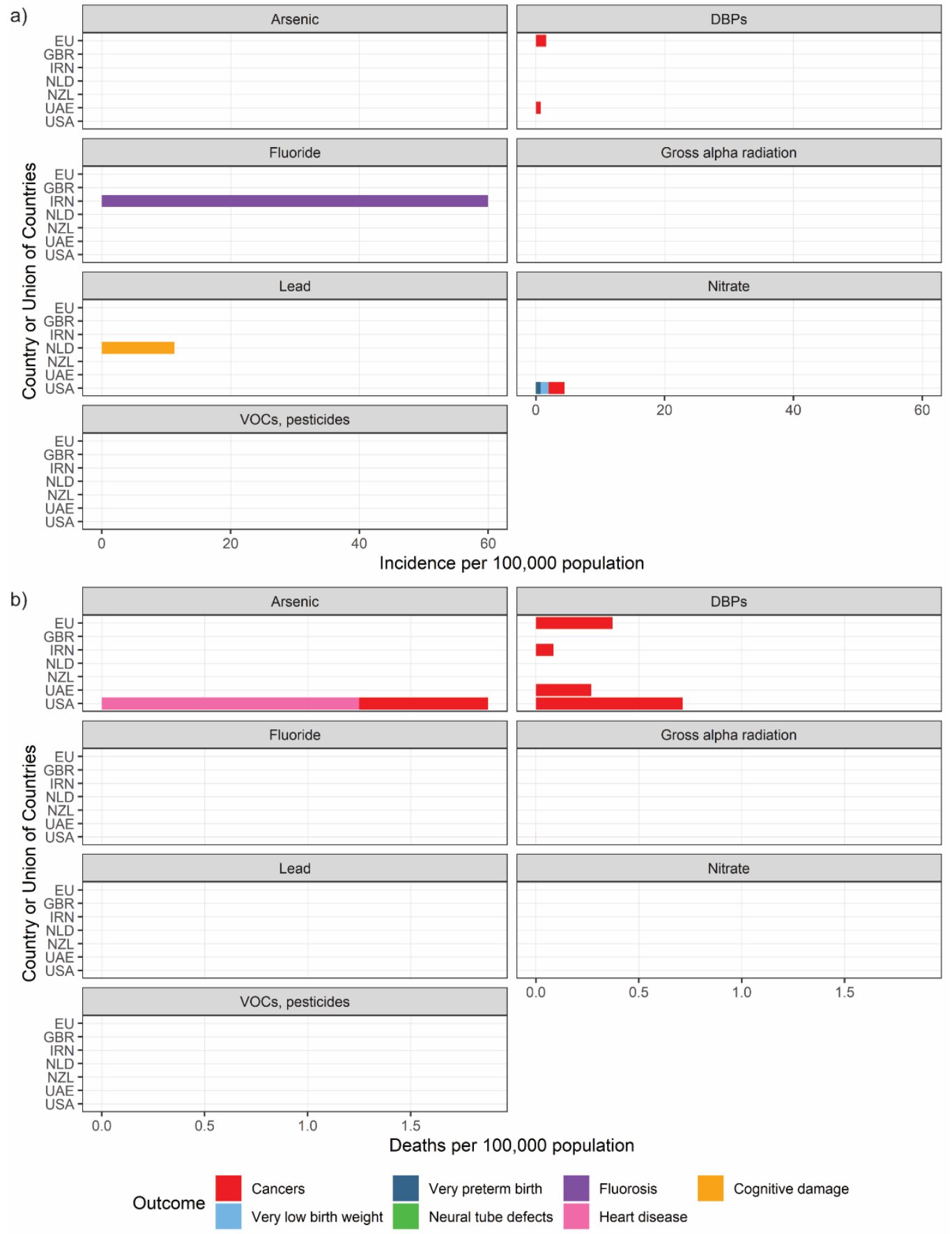

Figure 3. Summary of a) cases and b) deaths by chemical contaminant and country. For countries where disease burden estimates were available through multiple studies, disease outcome estimates from different studies were averaged to produce country-specific estimates. For cancers, specific cancer estimates (e.g. bladder cancer, liver cancer) were summed to produce an overall cancer estimate. Note: The burden of neural tube defects in the United States is not visible due to its relatively low level $(0.02$ cases per 100,000$)$

Countries: EU=European Union, GBR=United Kingdom, IRN=Iran, NLD=The Netherlands, UAE=United Arab Emirates, USA=United States of America Contaminant: DBPs=Disinfection by-products, VOCs=Volatile Organic Compounds 